\title{
How sensitive are individual retirement expectations to raising the retirement age?
}

Citation for published version (APA):

de Grip, A., Fouarge, D., \& Montizaan, R. M. (2013). How sensitive are individual retirement expectations to raising the retirement age? De Economist, 161(3), 225-251. https://doi.org/10.1007/s10645-013-9205-5

Document status and date:

Published: 01/01/2013

DOI:

10.1007/s10645-013-9205-5

Document Version:

Publisher's PDF, also known as Version of record

Document license:

Taverne

Please check the document version of this publication:

- A submitted manuscript is the version of the article upon submission and before peer-review. There can be important differences between the submitted version and the official published version of record.

People interested in the research are advised to contact the author for the final version of the publication, or visit the DOI to the publisher's website.

- The final author version and the galley proof are versions of the publication after peer review.

- The final published version features the final layout of the paper including the volume, issue and page numbers.

Link to publication

\footnotetext{
General rights rights.

- You may freely distribute the URL identifying the publication in the public portal. please follow below link for the End User Agreement:

www.umlib.nl/taverne-license

Take down policy

If you believe that this document breaches copyright please contact us at:

repository@maastrichtuniversity.nl

providing details and we will investigate your claim.
}

Copyright and moral rights for the publications made accessible in the public portal are retained by the authors and/or other copyright owners and it is a condition of accessing publications that users recognise and abide by the legal requirements associated with these

- Users may download and print one copy of any publication from the public portal for the purpose of private study or research.

- You may not further distribute the material or use it for any profit-making activity or commercial gain

If the publication is distributed under the terms of Article $25 \mathrm{fa}$ of the Dutch Copyright Act, indicated by the "Taverne" license above, 


\title{
How Sensitive are Individual Retirement Expectations to Raising the Retirement Age?
}

\author{
Andries de Grip • Didier Fouarge • \\ Raymond Montizaan
}

Published online: 1 April 2013

(C) Springer Science+Business Media New York 2013

\begin{abstract}
This paper investigates the causal effects of the announcement of an increase in the statutory pension age on employee retirement expectations. In June 2010, the Dutch government signed a new pension agreement with the employer and employee organizations that entailed an increase in the statutory pension age from 65 currently to 66 in 2020 for all inhabitants born after 1954. Given the expected increase in average life expectancy, it was also decided that in 2025 the pension age would be further increased to 67 for those born after 1959. This new pension agreement received huge media coverage. Using representative matched administrative and survey data of public sector employees, we find that the proposed policy reform increased the expected retirement age by 3.6 months for employees born between 1954 and 1959 and by 10.8 months for those born after 1959 . This increase is reflected in a clear shift in the retirement peak from age 65 to ages 66 and 67 for the respective treated cohorts. Men respond less strongly to the policy reform than women, but within couples we find no evidence that the retirement expectations of one spouse are affected by an increase in the statutory pension age of the other. Furthermore, we show that treatment effects are largely driven by highly educated individuals but are lower for employees whose job involves physically demanding tasks or managerial and supervisory tasks.
\end{abstract}

\footnotetext{
A. de Grip ROA, IZA, GSBE, NETSPAR, Maastricht University, P.O. Box 616, 6200 MD Maastricht, The Netherlands

e-mail: a.degrip@maastrichtuniversity.nl

D. Fouarge ( $\square)$

ROA, GSBE, NETSPAR, Maastricht University, P.O. Box 616, 6200 MD Maastricht, The Netherlands e-mail: d.fouarge@maastrichtuniversity.nl

R. Montizaan

ROA, GSBE, IZA, Maastricht University, P.O. Box 616, 6200 MD Maastricht, The Netherlands e-mail: r.montizaan@maastrichtuniversity.nl
} 
Keywords Retirement - Labor supply · Pension system reform ·

Cross-spouse effects

JEL Classification $\quad \mathrm{J} 14 \cdot \mathrm{J} 26$

\section{Introduction}

Increasing longevity is threatening the sustainability of pension systems in many industrialized countries (e.g., Gruber and Wise 1998; Bloom et al. 2007). The oldage dependency ratio and the period of time in which individuals claim retirement benefits have both been increasing dramatically in the past three decades (European Commission 2011). As a consequence, the Organisation for Economic Co-operation and Development (OECD) forecast that pension expenditures will increase to $12.7 \%$ of the gross domestic product in OECD countries by 2060 (OECD 2011). To maintain retirement income adequacy without endangering financial sustainability, a large majority of these countries will be forced to reduce the generosity of their pension systems and to increase the general awareness of pension risks and individual responsibility. Most European countries are already increasing statutory pension ages or will do so in the coming years. ${ }^{1}$ To determine whether such policy reforms will indeed be effective in reducing the financial pressure on pension systems, it is of great importance to gain better insights into how the labor supply at older ages responds to these changes in pension rules and the extent to which individuals adapt their retirement expectations in such a dynamic environment.

This paper analyzes the extent to which an announced increase in the eligibility age for the Dutch public old age pension affects individuals' retirement expectations. In June 2010, the Dutch government signed a new pension agreement (Pensioenakkoord) with the employer and employee organizations in which they agreed to increase the statutory pension age in 2020 from 65 to 66 years for all inhabitants born after 1954 . It was also decided that the increased retirement age should be reassessed every five years and aligned with the average life expectancy of the Dutch population. Under the condition of an expected rise in average life expectancy, it was agreed that in 2025 the pension age would be further increased to 67 for those born after 1959. This new pension agreement received large media coverage. As Manski (2004) argued, it is important to understand how people shape their expectations in light of new relevant information. Lamla and Lein (2008), for example, reported that individuals revise their expectations on inflation when media attention on the topic increases. ${ }^{2}$

\footnotetext{
1 For the latest overview of realized and planned pension reforms, see the European Commission (2012).

2 Van der Wiel (2009) focused on the extent to which media attention on old age pensions affects people's expectations about the Dutch old age social security system. Using data covering the period 2006-2008, she found that most of the variation in changes in expectations about the statutory pension age was driven by random shifts, whereas only zero to $30 \%$ (depending on subgroup characteristics) was driven by changes in media coverage. However, Van der Wiel (2009) investigated people's expectations on changes in the statutory pension age in general, without any reference to policy change. We focus on an announced pension reform with clear implications for pension age (see Sect. 2).
} 
Using matched administrative and survey data collected in April 2011 as a representative sample of public sector employees (public administration, education sector, and privatized organizations), we measure the effects of the announced increase in the eligibility age for the Dutch public old age pension on the expected age of retirement. Research indicates that such stated preferences are in line with actual individual behavior (Carson et al. 1996; Louviere et al. 2000). ${ }^{3}$ Our empirical analyses suggest that the policy reform increased the expected retirement age of the treated cohorts compared to that of the non-treated cohort. ${ }^{4}$ The expected retirement age is 3.6 months higher for employees born between 1954 and 1959 and 10.8 months higher for those born after 1959. ${ }^{5}$ Although a strong retirement peak remains at age 65 for both targeted cohorts, we observe a clear shift in the retirement peak to ages 66 and 67. A comparison of retirement expectations between men and women shows that men are less responsive to the policy reform. We furthermore exploit the announced policy change to analyze whether retirement expectations are affected by an increase in the statutory pension age of spouses. The estimates show no evidence of any spillover effects of incentives faced by respondents' spouses on their own retirement expectations. However, we do find that the effects of the policy reform are strongly heterogeneous with the education level of employees and whether their job involves highly physically demanding tasks or managerial and supervisory tasks.

This article goes beyond the earlier literature in several ways. First, because employees cannot choose their birth date, the effects we report are likely to be causal announcement effects of the state pension reform. Second, we provide evidence that the effects of a rise in the eligibility age for the state pension are heterogeneous with several personal, job, and household characteristics. Third, this is the first study that examines the causal ex ante effects of an announced increase in the eligibility age for the state pension on retirement expectations.

Most studies on retirement decisions have focused on the role of benefit generosity in determining the retirement decision (e.g., Hurd and Boskin 1984; Burtless 1986; Stock and Wise 1990; Krueger and Pischke 1992; Samwick 1998; Gruber and Wise 1999; Schils 2005; Coile and Gruber 2007; Liebman et al. 2009; Euwals et al. 2010). These studies documented that the level, accrual, or option value of retirement benefits have a significant but modest effect on retirement dates. More importantly, they also revealed strong retirement peaks at the age of first eligibility for early retirement and retirement benefits (e.g., Gruber and Wise 2007). This finding implies that an increase in the eligibility age for the state pension could effectively increase the retirement age. However, the retirement literature that specifically analyzes how strongly a rise in the eligibility age for state pensions affects the timing of retirement is sparse. This can

\footnotetext{
3 Stated preferences are increasingly used in economic studies that focus on labor supply (Kimball and Shapiro 2008) and retirement (Van Soest and Vonkova 2013).

4 Retirement benefits are traditionally thought to affect individual behavior through two channels: an income effect and a price effect (Euwals et al. 2010). The income effect refers to changes in behavior due to changes in lifetime income. The price effect refers to changes in behavior due to changes in marginal incentives for continued work. The increase in the eligibility age of the state pension predominantly entails an income effect on retirement behavior.

5 In the year after the survey was conducted, further reforms of the pension system were announced. Section 2.2 discusses these reforms in more detail.
} 
partly be explained by the fact that in many countries older people have not yet faced an increase of the statutory retirement age (Van Erp et al. 2008). For example, in Germany, the retirement age will gradually increase from 65 to 67 years during 2012-2030.

To our knowledge, only two empirical studies have conducted an ex post policy evaluation of an increase in the statutory retirement age. The first study analyzed a policy change in the United States that gradually increased the eligibility age for claiming retirement benefits from 65 to 67 (Mastrobuoni 2009). Since 2003, employees who were born in 1983 or later are confronted with an increase in the retirement age of 2 months per year, while nothing changed for older cohorts. A comparison between younger and older cohorts around this treatment threshold showed that the increase in the eligibility age for retirement benefits delayed retirement by approximately one month, although it is likely that the effects on the labor participation of younger cohorts that are not yet retired will be lower because they have more time to increase their private pension savings to accommodate for the pension reform. The second study analyzed the effects of a gradual increase in the Austrian eligibility age for retirement benefits in the period 2000-2006 (Staubli and Zweimüller 2011). The eligibility age was increased from 60 to 62 years and 2 months for men and from 55 to 57 years and 2 months for women. The authors found that the policy change has reduced retirement by $19 \%$ points among affected men and by $25 \%$ points among women. However, they also observed that the decline in retirement was accompanied by sizable spillover effects on the unemployment insurance program, implying that the likelihood of being employed increased by only $7 \%$ points for men and $10 \%$ points for women.

Most studies that attempted to quantify the effects of increasing the eligibility age for state pensions on the labor supply decisions of older employees have used simulation techniques or a stated preferences approach. These studies generally produce estimates that are lower than those reported in the expost policy evaluations of increases in the retirement age discussed above. Simulation studies generally use sophisticated life-cycle models for retirement that can thoroughly substantiate the potential effects of policy changes. The main drawback of these types of models is that the outcomes are highly dependent on the underlying assumptions of the employees (unobserved) expectations and opportunities. ${ }^{6}$ Nevertheless, various simulation studies have indicated that the effects of increasing the eligibility age on labor supply decisions are moderate. Fields and Mitchell (1984) and Gustman and Steinmeier (2004, 2005) estimated for the United States that a rise in the eligibility age from 65 to 67 years increased the average retirement age by only 2 months. However, Fehr et al. (2011) estimated for Germany that a similar increase in the eligibility age would, on average, induce employees to postpone their retirement by 11 months. For the Netherlands, Van Erp and de Hek (2009) estimated that a rise in the eligibility age from 65 to 67 years would increase the retirement age by one month, while a simulation study of the Netherlands Bureau for Economic Policy Analysis (CPB 2011) forecast that the planned rise in the eligibility age of the state pension in 2010 would increase the labor supply by only $0.2 \%$.

6 For example, Gustman and Steinmeier (1985) assumed that individuals have perfect foresight, while Van Erp and de Hek (2009) assumed that individuals do not face any uncertainty. 
The studies that used a stated preferences approach are largely consistent with the above-mentioned simulation studies. ${ }^{7}$ Van Soest et al. (2006) applied a stated preferences approach in which, besides variations in replacement ratios at different ages, explicit attention was paid to the effects of an increase in the eligibility age of the state pension from 65 to 67 years. Simulations based on the outcomes of the stated preferences showed that employees are reluctant to work full-time after age 65 . Bruinshoofd and Grob (2006) concluded that a two-year rise in the eligibility age of the state pension would lead to an increase in the retirement age of approximately 10 months. $^{8}$

This paper proceeds as follows. Section 2 provides some background information on the Dutch pension system and describes the announced policy change in more detail. Section 3 describes the data used, presents descriptive statistics, and outlines our empirical strategy. Section 4 describes our estimation results. Section 5 concludes the study.

\section{Reform of the Dutch Pension System}

\subsection{Dutch Pension System and Previous Reforms}

As in many other countries, the Dutch pension system consists of three pillars. The first pillar consist of a flat-rate public scheme (AOW) to which all residents are traditionally entitled as of the age of 65, regardless of whether they had been an employee, self-employed, or had never participated in the labor market. ${ }^{9}$ This statutory old-age pension provides Dutch residents with a pension benefit that in principle guarantees $70 \%$ of the net minimum wage for a single household and $50 \%$ for each partner in a couple (either married or officially living together). The second pillar is the supplementary earnings-related pension. This is a defined-benefit type of pension for employees organized at the sector or firm level. The third pillar includes all voluntarily built-up savings that are in addition to the first two pillars. Typically, these savings are annuities through an insurance company. Due to the well-established first two pillars of the Dutch pension system, however, the third pillar is less well developed in the Netherlands than in other countries.

\footnotetext{
7 Stated preferences analyses use an experimental setting in which individuals are presented hypothetical but realistic choice problems and are asked to choose between the different options.

8 Kerkhofs et al. (2009) introduced several financial incentives into their stated preferences approach to determine the income effect of an overall reduction in pensions and the price effects of making the Dutch pension system actuarially neutral. They found that the retirement expectations of individuals are sensitive to both types of incentives but that the price effect is significantly stronger. Other Dutch studies that applied a stated preferences approach have largely focused on the effects of the introduction of the pre-pension scheme.

9 Since its introduction 1957, the AOW has been intended to entitle all inhabitants aged 65 and over to full AOW old-age pension rights. Entitlement to the AOW pension is accumulated at a rate of $2 \%$ for each year of residency in the Netherlands between the ages of 15 and 64 . This leads to $100 \%$ entitlement to the pension benefit upon reaching the age of 65 . However, if one lived outside the Netherlands for some time, one will not accrue any AOW pension rights during that period unless one has paid a contribution for voluntary insurance.
} 
Since the 1990s, the Dutch pension system has undergone incremental but steady modernization. Pension reforms in the Netherlands to date, however, have focused on the second pillar of the pension system by reducing the ample opportunities for early retirement far before the statutory retirement age of 65 . These reforms were initiated by the Dutch government, which stopped the favorable tax treatment of early retirement schemes in the second pillar. The first major pension reform was the abolishment of the sector- or firm-specific early retirement schemes (VUT) (cf. Euwals et al. 2010). The second major reform was the further abolishment in 2006 of the pre-pension arrangements for all employees born in 1950 or later. The effects of this pension reform on various outcomes for those employed in the Dutch public sector were extensively documented by De Grip et al. (2012), Fouarge et al. (2011), Montizaan et al. (2012), and Montizaan and Vendrik (2012). ${ }^{10}$

\subsection{The Reform of the State Pension System}

After a long period of debate, the financial crisis of 2008 accelerated the need to reform the first pillar of the Dutch system, the public AOW scheme. Since its introduction in 1957 , this state pension was related to the statutory retirement age of 65 . In June 2010, a tripartite pension agreement was reached by employer organizations, trade unions, and the government. The agreement foresees a two-step postponement of the statutory pension age. The first step was to increase the pension age in 2020 from 65 to 66 years for all inhabitants born after 1954. Moreover, it was agreed that the retirement age should then be reassessed every five years to determine whether the average life expectancy warrants further raising the statutory pension age. From this perspective, it was expected at that time that in 2025 the pension age would be further increased to 67 for those born after $1959 .{ }^{11}$ This agreement was officially published in June 2011. ${ }^{12}$

In 2012, the change of the government coalition led, however, to severe amendments to this tripartite pension agreement. These included an acceleration of the speed by which the age at which someone becomes eligible for the state pension will be increased in the coming years: a stepwise increase from age 65 to 66 in 2018 and a further

10 In 2006, Dutch public sector employees experienced a dramatic reform of the second pillar of the pension system. Employees born before 1950 remain entitled to the old, generous pre-pension rights if they worked continuously in the public sector since April 1, 1997, while those born later are subject to a less generous system. Those born in 1950 or later experienced a drop in pension benefits, an increase in pension contribution payments to partly account for the drop in pension wealth due to the drop in pension benefits, and stronger incentives to continue working, generated by penalties on pension income for retiring before commencement of the state pension at age 65 and by supplements for later retirement.

11 Although the details of the pension reform were known to the public, the pension agreement was not yet legally implemented at the time we conducted our survey (see Sect. 3.1). Therefore, both increases in the retirement age were a probable outcome at the time of the survey.

12 In the original plan, the state pension would be guaranteed to rise in line with wage inflation until 2028 and would also increase by $0.6 \%$ annually from 2013 on. In addition, the state pension age would be made more flexible, with pension benefits reduced for early retirees and increased for later retirees. 
stepwise increase to 67 years in $2021 .{ }^{13}$ However, the data used in this paper were collected in April 2011. At that time, the tripartite pension agreement of 2010/2011 was generally seen as the new first pillar pension scheme. Between June 2010 and June 2011, this new pension agreement received a great deal of attention in the national as well as regional media, enabling individuals to anticipate the pension reform. ${ }^{14}$ As mentioned, the announced reform of the first pillar pension scheme created two discontinuities. The first discontinuity refers to the birth years 1950-1954 versus 19551959. Whereas those born in 1950-1954 could retire at the age of 65, those born in 1955-1959 could, according to the new pension rule, retire only at the age of 66 . The second discontinuity refers to those born in 1960 or later who are, according to the new pension rule, eligible for the state pension only at the age of 67 .

\section{Data and Empirical Strategy}

\subsection{Data}

We use matched administrative and survey data of Dutch public sector employees (the ROA Public Sector Survey 2011) to examine the announcement effects of the increase in the eligibility age for the state pension. The administrative data come from the Dutch pension fund for public sector employees (ABP) and contain information on the number of contribution years to the pension fund, the number of working hours, and the sub-sector in which the respondents are employed: public administration, education sector, or privatized organizations.

The survey data were collected in two stages. In the first stage, a representative sample of 38,700 public sector employees born between 1946 and 1975 were approached by the pension fund by regular mail. They were asked to provide their e-mail address. In the second stage, in the first week of April 2011, we sent an e-mail containing the link to our web-based survey to the 8,100 employees who had provided their e-mail address. ${ }^{15}$ The invitation letter and the e-mail conveyed general information about the social usefulness of the study but explicitly avoided any reference to the postponement of the eligibility age of the state pension. The survey asked detailed questions on retirement expectations, alternative sources of income after retirement, partner characteristics, and job characteristics.

\footnotetext{
13 This change of the pension scheme was introduced by the new Dutch government in May 2012. This new scheme was preceded by an agreement of other political parties with a majority in Parliament (the so-called Kunduz coalition) that postponed the eligibility age for the state pension to age 67 in 2023. The latter agreement was, however, overruled by the new government that came into power in autumn 2012.

14 A search in all national Dutch newspapers reveals that the word pension appears in 3,427 articles between June 2010 and June 2011 and the word pensioenakkoord appeared in 577 articles. Between June 2009 and June 2010, the words pensioen and pensioenakkoord appeared in 2,659 and 27 articles, respectively. An Internet search reveals more than 2,000 hits on pensioenakkoord between June 2010 and June 2011. Moreover, the public sector's pension fund officially issued a declaration in June 2011 to support the pension agreement.

15 As discussed in Sect. 2.2, this implies that the survey was conducted before the collapse of the Dutch government and the change of the government coalition, which led to renewed negotiations on additional major changes to the Dutch pension system.
} 
The initial sample of respondents working in the public sector who completed the questionnaire consists of 5,300 individuals. To avoid bias from a previous reform of the pension system, we exclude all individuals born before $1950 .{ }^{16}$ Furthermore, due to low response rates, we exclude all employees born after 1964. The final estimation sample thus comprises 3,500 employees, 2,000 of whom belong to the control group (born in 1950-1954) and 1,500 of whom belong to the groups of employees affected by the increase in the eligibility age of the state pension (born in 1955-1959 or 19601964). Table 6 of the "Appendix" shows that the response rate is $21 \%$ for the control group, $15 \%$ for the group of employees born between 1955 and 1959, and $10 \%$ for those born between 1960 and 1964. Table 7 of the "Appendix" shows probit estimates that substantiate that the selection into the survey was not related to the treatment. The marginal effects of two dummy variables that indicate whether individuals belong to one of the two affected birth cohorts are small and not statistically significant. We do observe, however, that the response rate is positively correlated with age, wages, the number of contribution years, and whether one works in the government or the education sector, while the response rate is lower among males and full-time employees. ${ }^{17}$

Table 1 presents summary statistics for the control group and the groups affected by the reform. The table documents only small differences between the different groups. Consistent with previous evidence (Euwals et al. 2011), we observe a higher female labor force share among the younger cohorts and a rapidly aging work force in the education sector. The strong aging trend combined with the higher level of education in this sector creates a positive age trend in education levels. The number of contribution years to the public sector's pension fund and wages are slightly higher for the control group. However, this reflects the limited age difference between the control and treatment groups. Finally, as could be expected, younger employees tend to work more overtime hours. They are also more often employed in jobs that involve physically demanding tasks and managerial and supervisory tasks.

\subsection{Descriptive Results}

Table 1 also provides descriptive evidence on the announcement effect of the pension reform on employees' retirement expectations. Retirement expectations are measured by the survey question, "When do you expect to retire?" Survey respondents could provide their expected age at retirement in full years and half-years. The table indicates that, on average, employees in the control group (born in 1950-1954) expect to retire at the age of 63 years and 9 months, while those eligible for a state pension at age 66 (born in 1955-1959) expect to postpone their retirement until they reach the age of 63 years and 10 months. Employees who have to wait until their 67 th birthday to become

\footnotetext{
16 Employees born before 1950 are still entitled to the old, more generous pre-pension rights if they worked continuously in the public sector since April 1, 1997 (see Sect. 2.1).

17 The state pension's share of the total individual pension wealth decreases with the pension wealth built up in the second pillar of the pension system. This share will therefore also depend on the wages and number of years employees contributed to their pension funds. The fact that individuals with lower wages and fewer contribution years were less inclined to participate in the questionnaire implies that we may be underestimating the impact of the policy reform on retirement age.
} 
Table 1 Sample statistics

\begin{tabular}{|c|c|c|c|}
\hline & $\begin{array}{l}\text { Control } \\
1950-1954\end{array}$ & $\begin{array}{l}\text { Treatment } \\
1955-1959\end{array}$ & $\begin{array}{l}\text { Treatment } \\
1960-1964\end{array}$ \\
\hline \multicolumn{4}{|l|}{ Personal characteristics } \\
\hline Age & $\begin{array}{l}59.06 \\
(1.38)\end{array}$ & $\begin{array}{l}54.08 \\
(1.44)\end{array}$ & $\begin{array}{l}49.05 \\
(1.41)\end{array}$ \\
\hline Male $(1=$ yes $)$ & $\begin{array}{l}0.64 \\
(0.48)\end{array}$ & $\begin{array}{l}0.58 \\
(0.49)\end{array}$ & $\begin{array}{l}0.52 \\
(0.49)\end{array}$ \\
\hline Number of contribution years & $\begin{array}{l}26.15 \\
(11.29)\end{array}$ & $\begin{array}{l}22.16 \\
(9.86)\end{array}$ & $\begin{array}{l}17.70 \\
(8.73)\end{array}$ \\
\hline Additional pension savings $(1=$ yes $)$ & $\begin{array}{l}0.42 \\
(0.49)\end{array}$ & $\begin{array}{l}0.44 \\
(0.50)\end{array}$ & $\begin{array}{l}0.44 \\
(0.50)\end{array}$ \\
\hline \multicolumn{4}{|l|}{ Education } \\
\hline Low education $(1=$ yes $)$ & $\begin{array}{l}0.08 \\
(0.27)\end{array}$ & $\begin{array}{l}0.09 \\
(0.29)\end{array}$ & $\begin{array}{l}0.10 \\
(0.30)\end{array}$ \\
\hline Average education ( $1=$ yes $)$ & $\begin{array}{l}0.27 \\
(0.48)\end{array}$ & $\begin{array}{l}0.30 \\
(0.46)\end{array}$ & $\begin{array}{l}0.33 \\
(0.47)\end{array}$ \\
\hline High education ( $1=$ yes $)$ & $\begin{array}{l}0.65 \\
(0.48)\end{array}$ & $\begin{array}{l}0.61 \\
(0.49)\end{array}$ & $\begin{array}{l}0.57 \\
(0.50)\end{array}$ \\
\hline \multicolumn{4}{|l|}{ Job characteristics } \\
\hline Public sector $(1=$ yes $)$ & $\begin{array}{l}0.42 \\
(0.49)\end{array}$ & $\begin{array}{l}0.44 \\
(0.49)\end{array}$ & $\begin{array}{l}0.51 \\
(0.50)\end{array}$ \\
\hline Education sector (1 = yes) & $\begin{array}{l}0.45 \\
(0.50)\end{array}$ & $\begin{array}{l}0.42 \\
(0.49)\end{array}$ & $\begin{array}{l}0.35 \\
(0.47)\end{array}$ \\
\hline Privatized organizations ( $1=$ yes $)$ & $\begin{array}{l}0.13 \\
(0.33)\end{array}$ & $\begin{array}{l}0.13 \\
(0.34)\end{array}$ & $\begin{array}{l}0.14 \\
(0.34)\end{array}$ \\
\hline Log of wages & $\begin{array}{l}10.66 \\
(0.51)\end{array}$ & $\begin{array}{l}10.65 \\
(0.48)\end{array}$ & $\begin{array}{l}10.58 \\
(0.49)\end{array}$ \\
\hline Work hours (full-time equivalent) & $\begin{array}{l}0.89 \\
(0.20)\end{array}$ & $\begin{array}{l}0.89 \\
(0.20)\end{array}$ & $\begin{array}{l}0.87 \\
(0.20)\end{array}$ \\
\hline Number of overtime hours & $\begin{array}{l}7.65 \\
(12.76)\end{array}$ & $\begin{array}{l}8.25 \\
(11.91)\end{array}$ & $\begin{array}{l}8.90 \\
(12.99)\end{array}$ \\
\hline Physically heavy tasks & $\begin{array}{l}1.16 \\
(2.27)\end{array}$ & $\begin{array}{l}1.31 \\
(2.42)\end{array}$ & $\begin{array}{l}1.42 \\
(2.62)\end{array}$ \\
\hline Managerial and supervisory tasks & $\begin{array}{l}3.29 \\
(3.26)\end{array}$ & $\begin{array}{l}3.64 \\
(3.26)\end{array}$ & $\begin{array}{l}3.77 \\
(3.27)\end{array}$ \\
\hline \multicolumn{4}{|l|}{ Partner characteristics } \\
\hline Partner (1 = yes) & $\begin{array}{l}0.86 \\
(0.34)\end{array}$ & $\begin{array}{l}0.84 \\
(0.37)\end{array}$ & $\begin{array}{l}0.85 \\
(0.35)\end{array}$ \\
\hline Age partner & $\begin{array}{l}57.86 \\
(4.78)\end{array}$ & $\begin{array}{l}53.86 \\
(4.94)\end{array}$ & $\begin{array}{l}49.10 \\
(5.09)\end{array}$ \\
\hline
\end{tabular}


Table 1 continued

\begin{tabular}{llll}
\hline & $\begin{array}{l}\text { Control } \\
1950-1954\end{array}$ & $\begin{array}{l}\text { Treatment } \\
1955-1959\end{array}$ & $\begin{array}{l}\text { Treatment } \\
1960-1964\end{array}$ \\
\hline Income partner (1=yes) & 0.81 & 0.87 & 0.89 \\
Retirement expectations & $(0.39)$ & $(0.34)$ & $(0.31)$ \\
Expected retirement age & & & 64.24 \\
& 63.77 & 63.85 & $(2.79)$ \\
\hline
\end{tabular}

Sample standard deviations are in parentheses below sample averages. The variables 'Physically heavy tasks' and 'Managerial and supervisory tasks' are self-reported measures. The answers to these two questions range between zero and 10, with zero meaning that individuals "never spend time" and 10 meaning that they "always spend time on these tasks in their work." Source ROA Public Sector Survey 2011

eligible for their state pension (born in 1960-1964) expect, on average, to retire at the age of 64 years and 3 months. The higher expected age at retirement for the treated cohorts suggests that they well perceive that the announced reform will affect their own retirement opportunities. However, the larger standard deviations for the cohorts affected by the reform also indicate that some employees affected by the reform may experience difficulties in fully understanding the consequences of the policy reform for their own pension rights.

Figure 1 adds to our understanding of the announcement effect of the reform on the expected retirement age by showing the percentages of employees, by birth year, who indicated that they expect to retire at the key age of 65,66 , or 67 . The figure shows that the percentage of employees who expect to retire at age 66 is highest for those born between 1955 and 1959. Of this age group, approximately $17 \%$ expect to retire at 66, which is $12 \%$ points higher than in the 1950-1954 cohort. Moreover, the percentage of employees who expect to retire at age 67 is the highest among those born between 1960 and 1964. Of all employees in this age group, $21 \%$ expect to retire at 67, which is about 18 percentage points higher than in the 1950-1954 cohort). However, the percentage of employees who expect to retire at age 65 is considerably lower among those born after 1954: $41 \%$ for those born between 1950 and 1954 versus $26 \%$ for the oldest cohort affected by the reform, and $30 \%$ for the youngest cohort affected by the reform.

The figure clearly shows that the differences in retirement expectations between the control group and the groups affected by the reform are indeed related to the increase in the eligibility age for the state pension. We observe strong discontinuities in the percentage of employees expecting to retire at the key age of 65,66 , or 67 between the birth years 1954 and 1955 as well as between the birth years 1959 and $1960 .{ }^{18}$ Since one's birth cohort is exogenous to the chosen threshold in the announced pension reform, we can conclude that there is a causal announcement effect of the pension

\footnotetext{
18 Figure 2 in the "Appendix" is comparable to Figure 1 but is based on data from the Dutch Labour Supply Panel, which were gathered in 2008, two years prior to the announced pension reform. This graph does not show any discontinuities between birth years 1954 and 1955 or birth years 1959 and 1960. This suggests that our 2011 data are indeed picking up a treatment effect that was not there before the announcement of the change in pension age.
} 


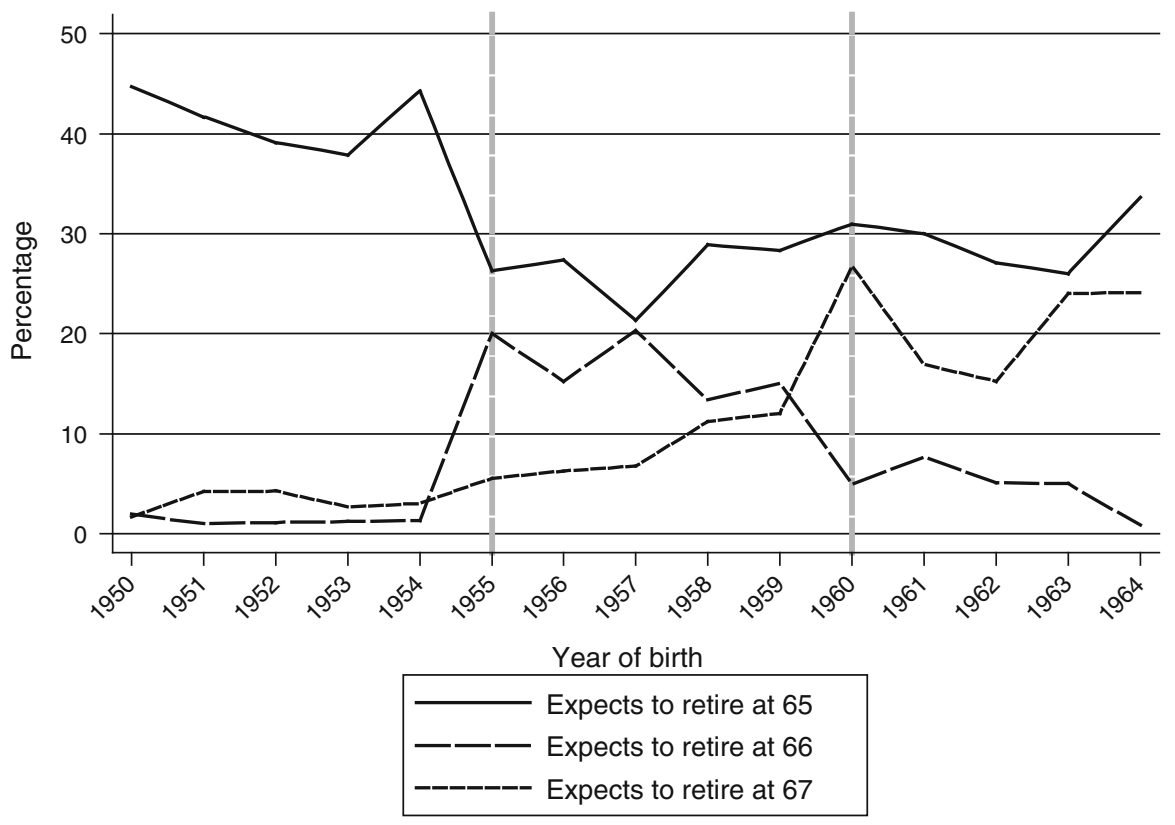

Fig. 1 Percentage of employees who expect to retire at age 65, 66, or 67, by birth year. Source: ROA Public Sector Survey 2011

reform on people's retirement expectations. However, the figure also shows that a large share of employees affected by the reform still expect to retire at age 65 . This may be due to their insufficient financial literacy, sticky preferences, a slow adaptation process, or simply a strong willingness among employees with a high pension wealth built up in the second and third pillars of the pension system to consume part of this wealth to enable retirement at age 65 .

\subsection{Empirical Strategy}

Our primary goal is to identify and quantify the treatment effects of the announced pension reform on the expected retirement age. In our main analyses, we first use ordinary least squares (OLS) regressions that take the following form: ${ }^{19}$

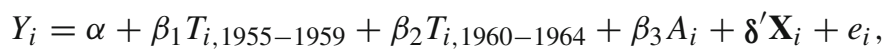

where $Y_{i}$ stands for the expected retirement age, $T_{i, 1955-1959}$ represents the treatment dummy indicating whether individuals are born in the birth years 1955-1959,

19 Using an ordered probit model rather than OLS does not affect our main results. In view of the high standard deviation of the expected retirement age reported in the last row of Table 1, we also performed quantile regressions to estimate the median value of the retirement age rather than the mean. This does not affect our main findings. 
$T_{i, 1960-1964}$ denotes the treatment dummy indicating whether individuals are born in the birth years 1960-1964, $A_{i}$ stands for the running age variable (age measured in days), $\mathbf{X}_{i}$ is a vector of control variables, and $e_{i}$ is the error term. The vector of control variables consists of a gender dummy, dummy variables indicating whether employees are low or highly educated (with an intermediate level of education as reference), the number of years contributed to the pension fund, the log of their wages, the number of weekly work hours (measure in full-time equivalents), and two dummy variables that denote whether individuals work in the public or education sector (with the privatized sector as reference).

The identifying assumption is that, in the absence of an increase in the eligibility age of the state pension, there should be no difference in $Y_{i}$ between age groups eligible for retirement benefits on age 65 (treatment groups) and those not eligible (comparison group) after controlling for background characteristics. Under this assumption, $\beta_{1}$ and $\beta_{2}$ will directly measure the average causal effects of the pension reform.

In a second step, we estimate a multinomial logit model, which provides a more parsimonious and flexible estimation approach to identify the treatment effects on the probability that individuals expect to retire at the specific eligibility ages $(65,66$, and 67 years) for the state pension. For this procedure, we collapsed all early retirement ages (ages 60 through 64) into one category that serves as the base category in our multinomial logit model. Due to the low number of employees who expect to retire after the age of 67, late retirement ages are likewise collapsed down to one category indicating whether one expects to retire at age 68 or later.

Previous studies document the large heterogeneity in expectations (Branch 2004; Van der Wiel 2009). We therefore perform a number of additional analyses to investigate the heterogeneity in treatment effects with respect to gender, the partner's socioeconomic position (the partner's income and treatment status), contribution years to the pension fund, additional pensions savings, level of education, and job tasks (overtime work, physically heavy tasks, and managerial and supervisory tasks).

\section{Results}

\subsection{Main Effects}

We now explore the impact of the announced pension reform on the expected retirement age. Columns 1 and 2 of Table 2 show OLS estimates on our key dependent variable without any control variables, while Column 3 presents the estimates of the model in Eq. (1). ${ }^{20}$ The table shows that the impact of the reform is relatively small and only weakly statistically significant among the oldest treated cohort, while there are stronger effects on the younger cohort affected by the reform. ${ }^{21}$ Employees born in

\footnotetext{
20 Tables 8 and 9 show the results of robustness analyses of estimations that do not include age as a control variable and include a higher-order polynomial of age.

21 There are several possible explanations for this. First, the older group of treated workers was exposed to the eligibility age of 65 for a longer period. A second explanation could be that older employees already built up more pension wealth in the second pillar of the pension system. The supplementary earnings-related pensions are based on the middle wage income since 2004, implying that younger cohorts will receive a
} 


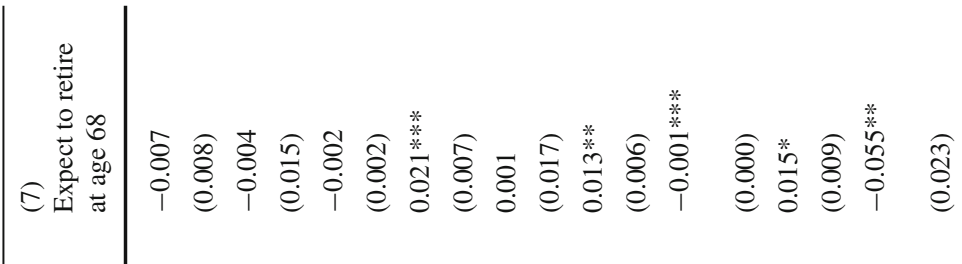

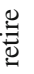

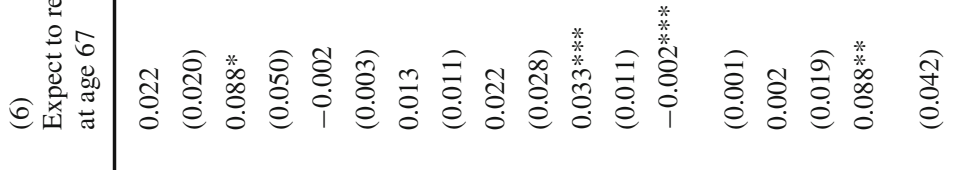

$\stackrel{0}{0}$

9

ڤิ)

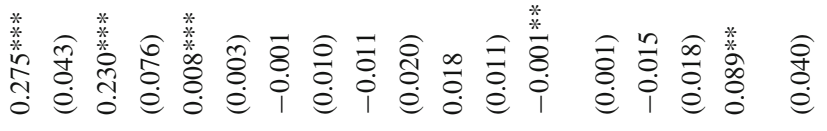

:

ㄴ.

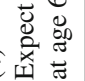

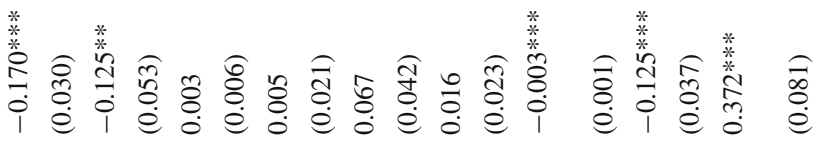

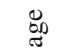

马 च

约齐竞

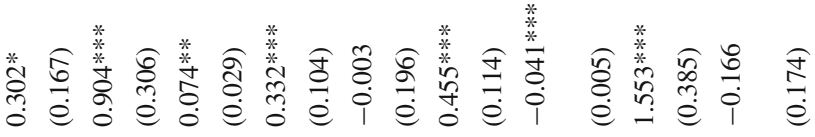

कू

马 छ

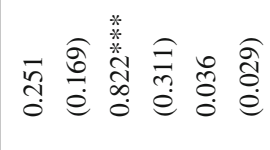

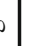

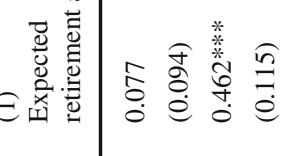

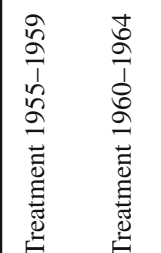

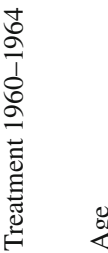

$\stackrel{0}{<} \quad \frac{0}{\pi}$

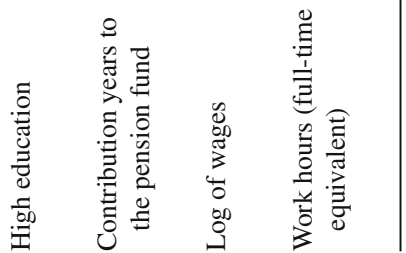




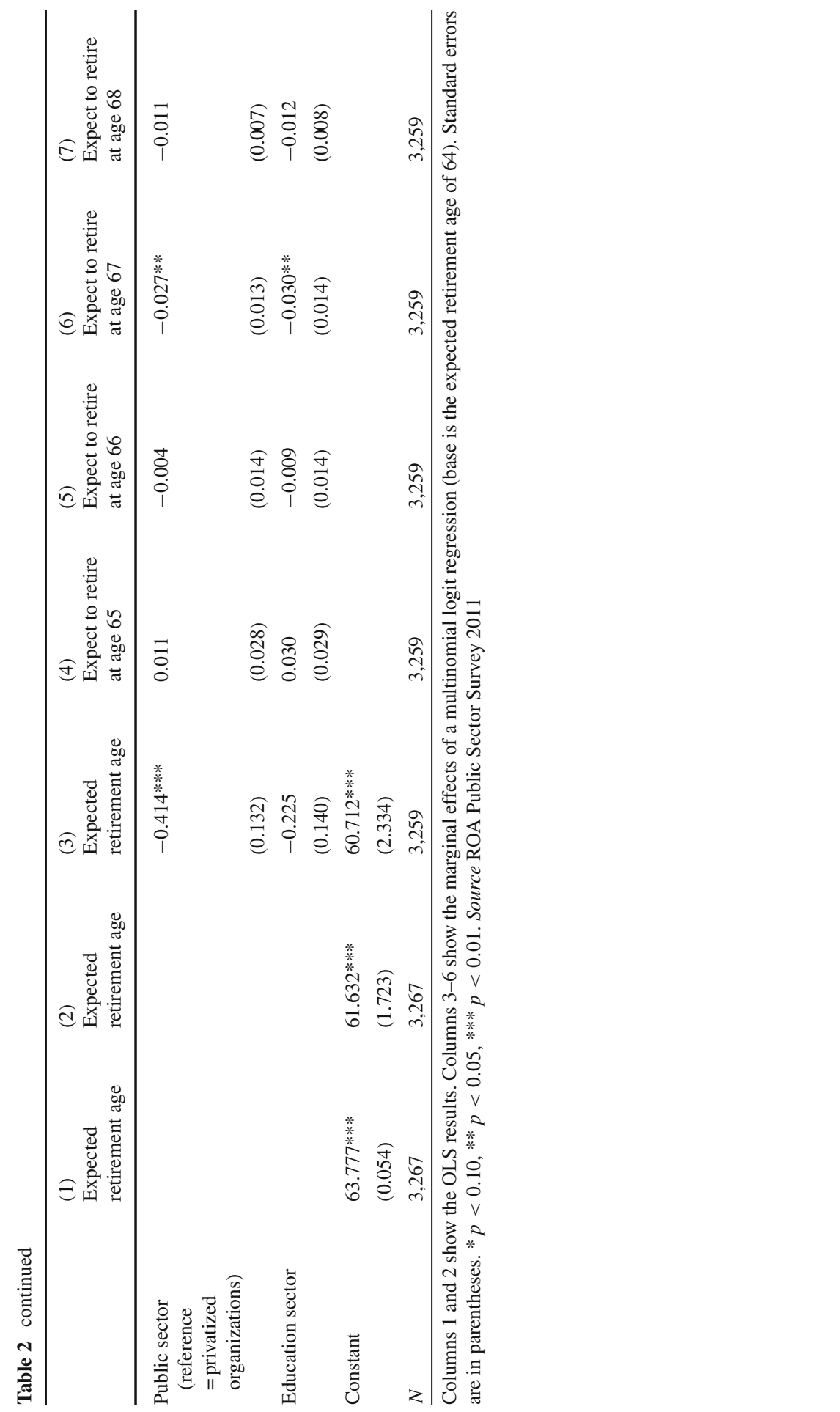


the years 1955-1959 whose eligibility age was postponed by one year expect to retire approximately 3.6 months later, while employees born in the years 1960-1964 whose eligibility age was postponed by two years expect to retire 10.8 months later. ${ }^{22}$ To check that this effect is a true announcement effect, we used the 2008 wave of the Dutch Labour Supply Panel that contains comparable information on the expected retirement age. Because these data were gathered two years before the announced change in the state pension age, the expected retirement age of the 1955-1959 and 1960-1964 cohorts should not differ from that of the 1950-1954 cohort. This is indeed the case (see Table 10 in the "Appendix").

The effects we found are considerably larger than those found in the simulation study by Van Erp and de Hek (2009). The latter showed that an increase in the eligibility age for the state pension by two years would only postpone the retirement age by one month. Our results are more consistent with those of Bruinshoofd and Grob (2006), who concluded that a rise of two years in the eligibility age of the state pension would lead to an increase in the retirement age of 10 months, and Mastrobuoni (2009), who found that an increase of 2 months in the eligibility age for retirement benefits delayed retirement by approximately one month.

The estimation results in Columns 3-6 identify the treatment effects on the probability that individuals expect to retire at the specific eligibility ages (ages 65, 66, and 67 years) for the state pension. The results confirm that the differences in the retirement expectations between the treatment groups and the control group are related to the announcement of the increase in the eligibility age for the state pension. As expected and illustrated in Figure 1, employees affected by the reform expect less often to retire at the old eligibility age of 65 . The probability of retiring at this age is $17 \%$ points lower among those born in 1954-1959 and approximately $13 \%$ points lower for those born after 1959. However, the expected probability of retiring at age 66 is significantly higher among both treatment groups. Consistent with the incentives given by the announced policy reform, the probability of retiring at age 66 is highest among those who become eligible for the state pension at this specific age (about 28 percentage points greater). Moreover, we only find a statistically significant treatment effect on the probability of retiring at age 67 for those born after 1959, while-consistent with the pension reform incentives - there is no significant effect for the cohorts born earlier. The probability of retiring at age 67 is nine percentage points greater for those born in 1960 or later. Finally, Table 2 shows that the probability of retiring at age 68 or later does not differ between the treatment and control groups.

\footnotetext{
Footnote 21 continued

relatively lower supplementary pension than older workers and are therefore more dependent on the state pension. Finally, the stronger treatment effect for younger cohorts may be due to the fact that they are generally more pessimistic about their pension rights due to the growing economic uncertainty.

22 In an additional analysis, we tested whether the treatment effects are biased due to self-selection into the survey. We performed a Heckman selection model on the expected retirement age that included all administrative variables in our dataset as independent variables in the selection equation. We find similar results to those presented in Table 2. The coefficient of the first treatment dummy is 0.290 (standard error 0.167), while the coefficient of the second treatment dummy is 0.902 (standard error 0.308).
} 


\subsection{Gender and Partner Analysis}

The analyses discussed above show a significant announcement effect of the pension reform on workers' retirement expectations. The purpose of the following analyses is to deepen our understanding of which groups are more strongly affected by the pension reform. A first crucial question is whether the effects are heterogeneous across genders. Indeed, earlier studies have found that financial incentives to continue working had strongly different effects on men and women. For example, Staubli and Zweimüller (2011) concluded that the gradual increase in the Austrian eligibility age for retirement benefits during 2000-2006 had a substantially stronger impact on the retirement patterns of women than on those of men. Moreover, a recent Dutch stated preferences study by Fouarge et al. (2012) revealed that women's retirement expectations are more sensitive to financial incentives-especially to the income effect generated by changes in pension wealth-than men's.

Column 1 of Table 3 presents estimates in which two interaction effects between the treatment dummies and the gender variable are added to the model. We find that men expect to retire 6.8 months later than women. More importantly, consistent with the results of the above-mentioned studies, we find that women are more sensitive than men to the pension reform, which predominantly entails an income effect. The interaction effect between the second treatment dummy and the gender dummy has a negative coefficient and is strongly statistically significant. The results imply that a man whose eligibility age for the statutory pension is increased by two years expects to retire only 6.9 months later than a man who is not treated by the reform, while a woman in a similar position expects to retire 17.4 months later than an untreated woman.

It is also relevant to put the effects of the announcement of the pension reform into a household context. Retirement has typically been seen as an event that affects the breadwinner of the family. However, the long-term increase in women's labor participation across the life course has led to an increasing number of couples with two retirement decisions to coordinate. A small number of studies have shown that the complementarities of leisure time have become an important determinant of joint retirement (Baker 2002; Coile 2004; Benitez-Silva and Dwyer 2006; Bingley and Lanot 2007; Ho and Raymo 2009; Stancanelli 2012). However, evidence is mixed regarding whether or not significant asymmetry exists in the sensitivity of retirement behavior of men and women with respect to the variation in their spouse's financial retirement incentives. Whereas Coile (2004) found that men are highly responsive to their wives' incentives and women are not responsive to their husbands' incentives, Bingley and Lanot (2007) showed that male eligibility accounts for a much larger proportion of a retirement program-induced fall in female participation than female eligibility accounts for a fall in male participation.

We therefore perform additional analyses in which we check whether the impact of the pension reform depends on the household context. For this analysis we selected respondents living in a couple who reported their partner's income and age. Column 2 of Table 3 shows the estimation results in which we include interaction effects between the treatment dummies and a dummy variable that indicates whether individuals have a spouse with his or her own income. Column 3 presents estimates in which the age of 
Table 3 Heterogeneous effects on the retirement age: Gender and partner analyses

\begin{tabular}{|c|c|c|c|}
\hline & $\begin{array}{l}\text { (1) } \\
\text { Expected } \\
\text { retirement age }\end{array}$ & $\begin{array}{l}(2) \\
\text { Expected } \\
\text { retirement age }\end{array}$ & $\begin{array}{l}\text { (3) } \\
\text { Expected } \\
\text { retirement age }\end{array}$ \\
\hline Treatment 1955-1959 & $\begin{array}{l}0.482 * * \\
(0.203)\end{array}$ & $\begin{array}{l}0.210 \\
(0.321)\end{array}$ & $\begin{array}{l}0.357^{*} \\
(0.197)\end{array}$ \\
\hline Treatment 1960-1964 & $\begin{array}{l}1.447 * * * \\
(0.338)\end{array}$ & $\begin{array}{l}0.932 * \\
(0.485)\end{array}$ & $\begin{array}{l}0.965 * * * \\
(0.371)\end{array}$ \\
\hline Male & $\begin{array}{l}0.567 * * * \\
(0.131)\end{array}$ & $\begin{array}{l}0.254^{*} \\
(0.130)\end{array}$ & $\begin{array}{l}0.121 \\
(0.147)\end{array}$ \\
\hline Treatment $1955-1959 \times$ male & $\begin{array}{l}-0.249 \\
(0.190)\end{array}$ & & \\
\hline Treatment 1960-1964 × male & $\begin{array}{l}-0.875 * * * \\
(0.233)\end{array}$ & & \\
\hline Income partner & & $\begin{array}{l}-0.144 \\
(0.156)\end{array}$ & \\
\hline Treatment $1955-1959 \times$ income partner & & $\begin{array}{l}0.158 \\
(0.299)\end{array}$ & \\
\hline Treatment $1960-1964 \times$ income partner & & $\begin{array}{l}0.101 \\
(0.387)\end{array}$ & \\
\hline Treatment partner $1955-1959$ & & & $\begin{array}{l}0.057 \\
(0.195)\end{array}$ \\
\hline Treatment partner 1960-1964 & & & $\begin{array}{l}-0.046 \\
(0.363)\end{array}$ \\
\hline Constant & $\begin{array}{l}60.123 * * * \\
(2.335)\end{array}$ & $\begin{array}{l}-48.250 * * \\
(20.718)\end{array}$ & $\begin{array}{l}-117.170 \\
(71.737)\end{array}$ \\
\hline $\begin{array}{l}\text { Control variables: age, gender, } \\
\text { education, contribution years to the } \\
\text { pension fund, work hours, log of } \\
\text { wages, industry dummies }\end{array}$ & Yes & Yes & Yes \\
\hline$N$ & 3,259 & 2,733 & 2,200 \\
\hline
\end{tabular}

Columns 1-3 show the OLS results. Standard errors are in parentheses. $* p<0.10$, ** $p<0.05$, *** $p<0.01$. Source ROA Public Sector Survey 2011

the spouse and two treatment dummies are included that indicate whether the spouse is born in the treatment years 1950-1954 or the years 1955-1959. The estimates in both columns show no evidence for any spillover effects of incentives faced by one spouse on the other's retirement expectations. ${ }^{23}$

23 We also estimated these models separately for men and women but again found no significant spillover effects. We also did not find significant spillover effects between spouses on the probability that individuals expect to retire at the specific eligibility ages for the state pension. 


\subsection{Pension Wealth and Education}

The share of the state pension in total individual pension wealth decreases with the pension wealth that has been built up in the second and third pillars of the pension system. This finding means that we can expect that the impact of the announcement of the policy reform will be lower for employees with more contribution years to their pension fund and for those who privately invested in additional pension products. Column 1 of Table 4 shows that treated employees who built up more pension rights in the second pillar of the pension system (information available from the administrative data) are indeed less affected by the pension reform. The effects range from 0.3 month (1960-1964 cohort) to 0.5 month (1955-1959 cohort) earlier retirement for each additional year a treated employee contributed to the pension fund. Column 2 presents estimates in which interaction terms are introduced between the treatment dummies and a dummy variable indicating whether an individual privately invested in additional pension products. The information on investments in additional pension products is based on answers to the following survey question: "Did you, besides your regular pension contributions to your pension fund, invest privately in additional products?" The coefficients of the interaction effects have the expected sign but are statistically insignificant. As mentioned before, this could be due to the fact that the third pillar of the Dutch pension system is far less well developed than the first two pillars. $^{24}$

Column 3 of Table 4 further gives the estimation results of our model, including interaction effects, with a dummy variable indicating whether employees are highly educated (measured as having a university degree or a degree from a university of applied sciences). Educational attainment can serve as a crude proxy for financial literacy and/or the interest that individuals have in their future retirement. It is well known that education plays a critical role in equipping individuals with an abstract level of thinking and the knowledge required to make strategic retirement decisions and to understand the impact of the policy reform on their own situation. ${ }^{25}$ We observe that the treatment effects are indeed largely driven by highly educated individuals, while the announcement effect for low-educated employees is not significantly different from zero. This finding hints to the need for more training to improve the level of financial literacy of low-educated individuals.

\footnotetext{
24 In estimations of the probability of individuals retiring at the specific eligibility ages for the state pension, we find that the treatment effects on the percentage of people who expect to retire at age 65,66 , or 67 strongly depends on the number of contribution years and additional private savings. We observe that additional pension savings significantly reduce the likelihood that individuals in the first treatment group will retire at age 66, while it does not affect the likelihood of retiring at age 67. However, having additional pension savings does reduce the likelihood of retiring at age 67 for the second treatment group.

25 The positive correlation between the level of education and retirement age can also be explained by the more favorable job characteristics of the highly educated. However, we performed an additional analysis that also included the demanding job characteristics and their interaction terms with the treatment dummies, presented in Sect. 4.4, and found that the interaction effects between education and the treatment dummies are robust to the inclusion of these variables.
} 
Table 4 Heterogeneous effects on the retirement age: Pension wealth and education

\begin{tabular}{|c|c|c|c|}
\hline & $\begin{array}{l}(1) \\
\text { Expected } \\
\text { retirement age }\end{array}$ & $\begin{array}{l}(2) \\
\text { Expected } \\
\text { retirement age }\end{array}$ & $\begin{array}{l}(3) \\
\text { Expected } \\
\text { retirement age }\end{array}$ \\
\hline Treatment 1955-1959 & $\begin{array}{l}0.962 * * * \\
(0.298)\end{array}$ & $\begin{array}{l}0.398 * * \\
(0.184)\end{array}$ & $\begin{array}{l}0.052 \\
(0.214)\end{array}$ \\
\hline Treatment 1960-1964 & $\begin{array}{l}1.939 * * * \\
(0.424)\end{array}$ & $\begin{array}{l}0.996 * * * \\
(0.320)\end{array}$ & $\begin{array}{l}0.485 \\
(0.343)\end{array}$ \\
\hline Contribution years to the pension fund & $\begin{array}{l}-0.031^{* * *} \\
(0.006)\end{array}$ & $\begin{array}{l}-0.043^{* * *} \\
(0.005)\end{array}$ & $\begin{array}{l}-0.041^{* * *} \\
(0.005)\end{array}$ \\
\hline $\begin{array}{l}\text { Treatment } 1955-1959 \times \text { Contribution } \\
\text { years to the pension fund }\end{array}$ & $\begin{array}{l}-0.024 * * \\
(0.010)\end{array}$ & & \\
\hline $\begin{array}{l}\text { Treatment } 1960-1964 \times \text { Contribution } \\
\text { years to the pension fund }\end{array}$ & $\begin{array}{l}-0.045^{* * *} \\
(0.013)\end{array}$ & & \\
\hline Additional pension savings & & $\begin{array}{l}-0.178 \\
(0.110)\end{array}$ & \\
\hline Treatment 1955-1959 × Additional pension savings & & $\begin{array}{l}-0.226 \\
(0.187)\end{array}$ & \\
\hline Treatment 1960-1964 × Additional pension savings & & $\begin{array}{l}-0.313 \\
(0.230)\end{array}$ & \\
\hline High education & $\begin{array}{l}0.440 * * * \\
(0.114)\end{array}$ & $\begin{array}{l}0.487 * * * \\
(0.114)\end{array}$ & $\begin{array}{l}0.238^{*} \\
(0.139)\end{array}$ \\
\hline Treatment $1955-1959 \times$ high education & & & $\begin{array}{l}0.368 * \\
(0.198)\end{array}$ \\
\hline Treatment $1960-1965 \times$ high education & & & $\begin{array}{l}0.645 * * * \\
(0.238)\end{array}$ \\
\hline Constant & $\begin{array}{l}59.720 * * * \\
(2.344)\end{array}$ & $\begin{array}{l}60.933 * * * \\
(2.333)\end{array}$ & $\begin{array}{l}60.859 * * * \\
(2.332)\end{array}$ \\
\hline $\begin{array}{l}\text { Control variables: age, gender, } \\
\text { education, contribution years to the } \\
\text { pension fund, work hours, log of } \\
\text { wages, industry dummies }\end{array}$ & Yes & Yes & Yes \\
\hline$N$ & 3,259 & 3,246 & 3,259 \\
\hline
\end{tabular}

Columns 1-3 show the OLS results. Standard errors are in parentheses. * $p<0.10$, ** $p<0.05$, *** $p<0.01$. Source ROA Public Sector Survey 2011

\subsection{Job Tasks}

Ever since the Dutch government started the discussion to increase the eligibility age for the statutory pension, there has been an extensive debate on whether this is feasible for employees who are employed in physically demanding jobs (Borghans and ter Weel 2012). Table 5 reports the estimates for the expected retirement age, where we control for demanding job characteristics_-overtime hours, physically demanding 
Table 5 Heterogeneous effects on the retirement age: Tasks

\begin{tabular}{|c|c|c|c|}
\hline & $\begin{array}{l}\text { (1) } \\
\text { Expected } \\
\text { retirement age }\end{array}$ & $\begin{array}{l}(2) \\
\text { Expected } \\
\text { retirement age }\end{array}$ & $\begin{array}{l}(3) \\
\text { Expected } \\
\text { retirement age }\end{array}$ \\
\hline Treatment 1955-1959 & $\begin{array}{l}0.461 * * \\
(0.179)\end{array}$ & $\begin{array}{l}0.403 * * \\
(0.174)\end{array}$ & $\begin{array}{l}0.580 * * * \\
(0.196)\end{array}$ \\
\hline Treatment 1960-1964 & $\begin{array}{l}0.967 * * * \\
(0.315)\end{array}$ & $\begin{array}{l}0.927 * * * \\
(0.314)\end{array}$ & $\begin{array}{l}1.151 * * * \\
(0.334)\end{array}$ \\
\hline Overtime hours & $\begin{array}{l}0.007 \\
(0.004)\end{array}$ & & \\
\hline Treatment $1955-1959 \times$ Overtime hours & $\begin{array}{l}-0.018 * * \\
(0.008)\end{array}$ & & \\
\hline Treatment 1960-1964 × Overtime hours & $\begin{array}{l}-0.006 \\
(0.009)\end{array}$ & & \\
\hline Physically heavy tasks & & $\begin{array}{l}-0.044 \\
(0.027)\end{array}$ & \\
\hline $\begin{array}{r}\text { Treatment } 1955-1959 \times \\
\text { Physically heavy tasks }\end{array}$ & & $\begin{array}{l}-0.090 * \\
(0.047)\end{array}$ & \\
\hline $\begin{array}{r}\text { Treatment } 1960-1964 \times \\
\text { Physically heavy tasks }\end{array}$ & & $\begin{array}{l}-0.001 \\
(0.053)\end{array}$ & \\
\hline Managerial and supervisory tasks & & & $\begin{array}{l}0.008 \\
(0.017)\end{array}$ \\
\hline $\begin{array}{l}\text { Treatment } 1955-1959 \times \text { Managerial } \\
\text { and supervisory tasks }\end{array}$ & & & $\begin{array}{l}-0.072 * * \\
(0.029)\end{array}$ \\
\hline $\begin{array}{l}\text { Treatment } 1960-1964 \times \text { Managerial } \\
\text { and supervisory tasks }\end{array}$ & & & $\begin{array}{l}-0.061 * \\
(0.035)\end{array}$ \\
\hline Constant & $\begin{array}{l}60.564 * * * \\
(2.351)\end{array}$ & $\begin{array}{l}61.738 * * * \\
(2.377)\end{array}$ & $\begin{array}{l}59.710 * * * \\
(2.362)\end{array}$ \\
\hline $\begin{array}{l}\text { Control variables: age, } \\
\text { gender, education, } \\
\text { contribution years to the } \\
\text { pension fund, work hours, } \\
\text { log of wages, industry } \\
\text { dummies }\end{array}$ & yes & yes & yes \\
\hline$N$ & 3,259 & 3,224 & 3,233 \\
\hline
\end{tabular}

Columns 1-3 show the OLS results. Standard errors are in parentheses. $* p<0.10$, ** $p<0.05$, *** $p<0.01$. Source ROA Public Sector Survey 2011

tasks, and managerial and supervisory tasks-and their interaction with the treated cohorts. Overtime hours (measured as the number of overtime hours in the previous month) are unrelated to the expected retirement age in the control group (Column 1 in Table 5). For the treated in the 1955-1959 cohort, overtime hours are negatively and significantly related to the expected retirement age: Employees in that cohort expect 
to retire 0.2 month earlier for each hour of overtime compared to those in the control group. ${ }^{26}$ However, overtime hours have no effect on the expected retirement age of employees in the 1960-1964 birth cohort. An explanation for these small and nonsignificant effects could be that overtime hours are most often not a structural feature of the job.

Column 2 of Table 5 reports the heterogeneous treatment effect for having a physically demanding job. Respondents were asked to report (on a scale from zero to 10) how often they spend time on physically demanding tasks such as carrying heavy objects or operating machinery. As expected, employees who perform physically demanding tasks expect to retire earlier. Although this effect is not significant for the control group, ${ }^{27}$ it is for the treated individuals in the 1955-1959 cohort: A one point increase on the scale of physically demanding tasks leads to a one-month decrease in the expected retirement age. Again, the effect is not significant for the 1960-1964 cohort, possibly because employees in that cohort are younger and do not yet perceive physically demanding tasks as a burden or because they expect to be able to adapt their tasks or change jobs later in their career. ${ }^{28}$

Carrying out managerial and supervisory tasks could indicate involvement in a mentally demanding job, which is potentially related to the decision to retire earlier. Respondents were asked to report (on a scale from zero to 10) how often they spend time on managerial tasks and on the supervision of other employees. We averaged their answers to both questions. Column 3 of Table 5 reports the results of the heterogeneous treatment effect on the extent to which employees are involved in such tasks. For the two treated cohorts, we find a negative and significant relation between the time spent on managerial and supervisory tasks and the expected retirement age. The effects range from 0.7 month (1960-1964 cohort) to 0.9 month (1955-1959 cohort) earlier retirement for each point increase on the scale used.

\section{Conclusion}

This paper examines the extent to which the retirement age of employees is sensitive to an announcement of an increase in the statutory pension age. Earlier simulation studies and stated preferences experiments suggest that an increase in the statutory pension age could induce employees to retire later. However, the magnitude of the effects reported in the literature varies and crucially depends on the assumptions made in the various studies. Ex post quantifications of the effect of raising the statutory pension age are rare since most countries only recently embarked on the path of policy reforms aimed

\footnotetext{
26 For this computation, we assume that a full-time working year counts 255 working days.

27 This lack of significance could also be caused by the relative homogeneity of the sectors included in our data. Using the 2008 wave of the Dutch Labour Supply Panel—which covers all sectors of industry in the Dutch economy - we find that those who are employed in physically demanding jobs expect to retire earlier.

28 Using 2008 data from the Dutch Labour Supply Panel, we find that workers in the 1960-1964 cohort are significantly less likely to report that physically demanding tasks are a burden to them compared to workers in the 1950-1954 cohort. There is no significant difference in the perceived burden of physically demanding tasks between the 1955-1959 and 1950-1954 cohorts.
} 
at raising the statutory pension age. This study therefore focuses on the announcement effects of a major Dutch pension reform initiated by the employer organizations, trade unions, and the government in June 2010 that resulted in an official pension agreement in June 2011. The agreement entails an increase of the statutory pension age from 65 to 66 years in 2020 for people born in the years 1955-1959 and to 67 in 2025 for those born after 1959. Using matched administrative and survey data gathered in April 2011 from Dutch public sector employees, we test the effect of this reform on retirement expectations. Since this change in the retirement age received a great deal of media attention, it is well suited for the study of the announcement effect of such a reform. Moreover, because the reform is exogenous to the employees since they cannot choose their birth date, the effects we report are likely to be causal. Although we focus on retirement expectations, the literature on stated preferences suggests these expectations are related to actual behavior.

Our analyses compare two treated cohorts (birth years 1955-1959 and 1960-1964) to a control cohort (1950-1954). Employees born in the years 1955-1959 whose pension eligibility age was postponed by one year expect to retire approximately 3.6 months later, while employees born in the years 1960-1964 whose eligibility age was postponed by two years expect to retire 10.8 months later. Further analyses of employees' retirement expectations show expected retirement peaks at ages 66 and 67 for the treated cohorts, thereby suggesting that the announced reform introduced a shift in the traditional latest retirement age. Employees affected by the reform expect less often to retire at the old eligibility age of 65 . Consistent with the incentives given by the policy reform, the probability of expected retirement at age 66 is highest among those born in the years 1955-1959, whereas we find that the retirement peak at age 67 is only statistically significant for the 1960-1964 cohort. We claim that these effects are true announcement effects since we do not observe similar patterns for these cohorts when using data gathered before the announced retirement reform.

We further find that the announcement effects of this reform on retirement age has heterogeneous effects across employees. In accordance with prior findings in the literature, the treatment effect, which predominantly entails an income effect, is mainly driven by female employees (cf. Bingley and Lanot 2007). However, when we focus on couples, we do not find that the partner's income or treatment status has significant effects on the respondent's own expected retirement age. This last finding is in line with Stancanelli (2012), who investigated the cross-spouse effects of a French reform on early retirement.

We also find that the treatment effects are largely driven by highly educated employees. The announcement effect for low-educated employees is not significantly different from zero. Moreover, the treatment effect appears to depend on the number of accumulated contribution years. This finding illustrates that more contribution years are associated with a lower sensitivity to the announced pension reform because workers have a higher second pillar pension. One's own pension savings, however, are unrelated to the expected retirement age, as well as to the pension reform treatment. Finally, we find that the magnitude of the treatment effect depends on job tasks. The announcement effect of the pension reform is smaller for employees whose job includes tasks that are highly physically demanding and for employees with intensive managerial and supervisory tasks. 
Since the old-age dependency ratio and time period in which individuals claim retirement benefits have been increasing in the past decades, various countries have started to gradually increase the statutory retirement age and other countries are now developing plans to do so. Our research suggests that such policies can indeed induce individuals to postpone their retirement, although to a lesser degree than the announced rise in the eligibility age.

Acknowledgements We gratefully acknowledge ABP for making the administrative data available for this research. We thank the Netspar Editorial Board, participants to the Netspar workshop Stoppen met werken: wat bepaalt wanneer? (The Hague), participants to the WSE Arbeidsmarktcongres (Leuven), and two anonymous referees for their helpful comments

\section{Appendix}

See Fig. 2 and Tables 6, 7, 8, 9 and 10.

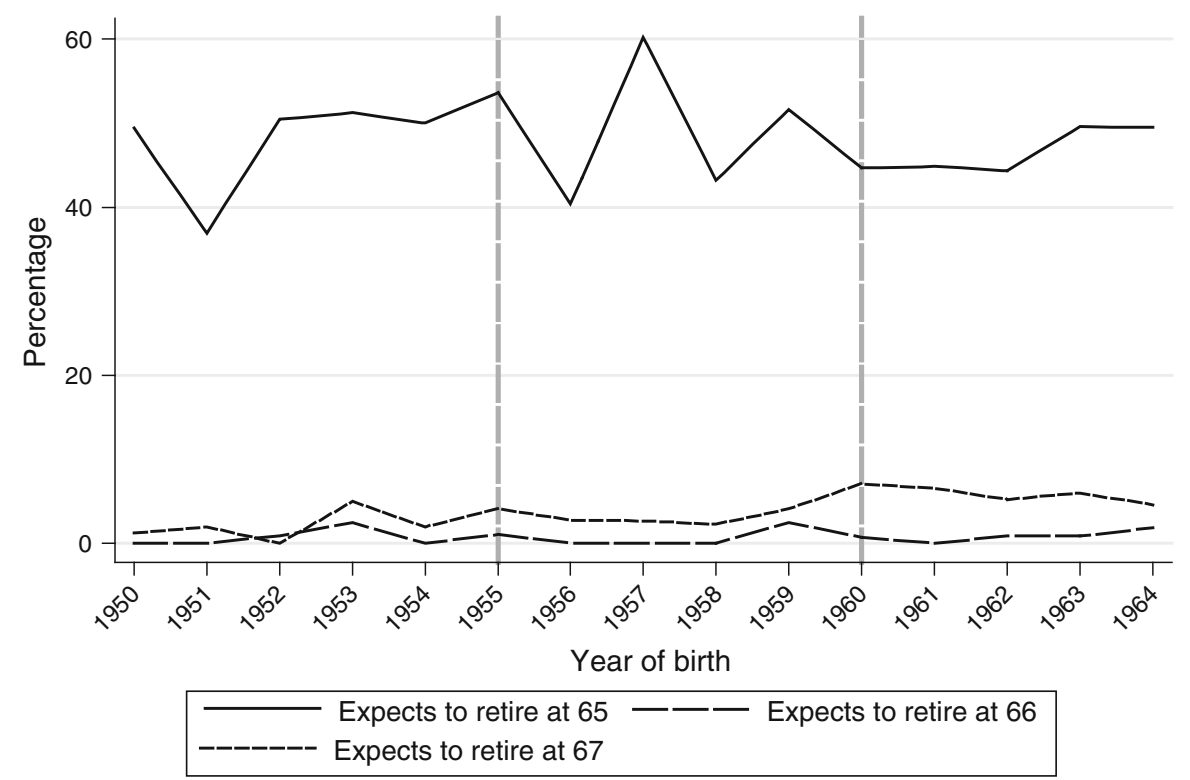

Fig. 2 Percentage of employees who expect to retire at age 65, 66, or 67, by birth year, 2008 . Source: Dutch Labour Supply Panel 2008

Table 6 Response to the survey

Source ROA Public Sector Survey 2011

\begin{tabular}{lrcl}
\hline & Sample & Response rates & Percentage \\
\hline Control 1950-1954 & 9,456 & 1,973 & 21 \\
Treatment 1955-1959 & 6,674 & 997 & 15 \\
Treatment 1960-1964 & 5,803 & 563 & 10 \\
Total & 21,933 & 3,533 & 16 \\
\hline
\end{tabular}


Table 7 Selection into the survey

This table shows the marginal effects of probit estimates on a dummy variable that measures whether individuals participated into the survey. All independent variables are from the administrative files of the pension fund. Standard errors are in parentheses. $* p<0.10$, $* * p<0.05$, *** $p<0.01$.

Source ROA Public Sector Survey 2011
(1)

Survey participation

\begin{tabular}{lc}
\hline Treatment 1955-1959 & -0.006 \\
Treatment 1960-1964 & $(0.010)$ \\
& -0.014 \\
Age & $(0.018)$ \\
& $0.008 * * *$ \\
Male & $(0.002)$ \\
& $-0.032 * * *$ \\
Log of wages & $(0.006)$ \\
& $0.080 * * *$ \\
Contribution years to the pension fund & $(0.008)$ \\
& $0.003 * * *$ \\
Work hours (full-time equivalent) & $(0.000)$ \\
& $-0.082 * * *$ \\
Public sector (reference & $(0.020)$ \\
= privatized & $0.026 * * *$ \\
organizations) & \\
Education sector & $(0.008)$ \\
\end{tabular}

Table 8 Main results: Effects on choice of retirement age (without controlling for age)

\begin{tabular}{|c|c|c|c|c|}
\hline & $\begin{array}{l}(1) \\
\text { Expect to retire } \\
\text { at age } 65\end{array}$ & $\begin{array}{l}(2) \\
\text { Expect to retire } \\
\text { at age } 66\end{array}$ & $\begin{array}{l}(3) \\
\text { Expect to retire at } \\
\text { age } 67\end{array}$ & $\begin{array}{l}(4) \\
\text { Expect to retire at } \\
\text { age } 68\end{array}$ \\
\hline Treatment 1955-1959 & $\begin{array}{l}-0.162 * * * \\
(0.018)\end{array}$ & $\begin{array}{l}0.181 * * * \\
(0.018)\end{array}$ & $\begin{array}{l}0.045^{* * * *} \\
(0.014)\end{array}$ & $\begin{array}{l}0.002 \\
(0.006)\end{array}$ \\
\hline Treatment 1960-1964 & $\begin{array}{l}-0.126^{* * * *} \\
(0.022)\end{array}$ & $\begin{array}{l}0.068 * * * \\
(0.026)\end{array}$ & $\begin{array}{l}0.154 * * * \\
(0.024)\end{array}$ & $\begin{array}{l}0.018 * * \\
(0.009)\end{array}$ \\
\hline $\begin{array}{l}\text { Control variables: } \\
\text { gender, education, } \\
\text { contribution years to } \\
\text { the pension } \\
\text { fund, work hours, } \\
\text { log of wages, } \\
\text { industry dummies }\end{array}$ & Yes & Yes & Yes & Yes \\
\hline $\mathrm{N}$ & 3,259 & 3,259 & 3,259 & 3,259 \\
\hline
\end{tabular}

Columns 1-4 show the marginal effects of a multinomial logit regression (base is expected retirement age of 64). Standard errors are in parentheses. * $p<0.10$, $* * p<0.05, * * * p^{*} p 0.01$. Source ROA Public Sector Survey 2011 
Table 9 Main results: Effects on retirement (including higher-order polynomial)

\begin{tabular}{|c|c|c|c|c|c|}
\hline & $\begin{array}{l}\text { (1) } \\
\text { Expected } \\
\text { retirement age }\end{array}$ & $\begin{array}{l}\text { (2) } \\
\text { Expect to retire } \\
\text { at age } 65\end{array}$ & $\begin{array}{l}\text { (3) } \\
\text { Expect to retire } \\
\text { at age } 66\end{array}$ & $\begin{array}{l}(4) \\
\text { Expect to retire } \\
\text { at age } 67\end{array}$ & $\begin{array}{l}(5) \\
\text { Expect to retire } \\
\text { at age } 68\end{array}$ \\
\hline \multirow{2}{*}{$\begin{array}{l}\text { Treatment } \\
1955-1959\end{array}$} & $0.351 * *$ & $-0.155^{* * *}$ & $0.252 * * *$ & 0.013 & -0.006 \\
\hline & $(0.169)$ & $(0.034)$ & $(0.056)$ & $(0.023)$ & $(0.010)$ \\
\hline \multirow{2}{*}{$\begin{array}{l}\text { Treatment } \\
1960-1964\end{array}$} & $0.698^{* *}$ & $-0.151 * * *$ & $0.231 * * *$ & $0.079 *$ & -0.003 \\
\hline & $(0.332)$ & $(0.056)$ & $(0.075)$ & $(0.048)$ & $(0.015)$ \\
\hline \multirow[t]{2}{*}{ Age } & -0.599 & -0.137 & 0.049 & 0.042 & -0.003 \\
\hline & $(0.419)$ & $(0.090)$ & $(0.062)$ & $(0.042)$ & $(0.023)$ \\
\hline \multirow[t]{2}{*}{ Age squared } & 0.006 & 0.001 & -0.000 & -0.000 & 0.000 \\
\hline & $(0.004)$ & $(0.001)$ & $(0.001)$ & $(0.000)$ & $(0.000)$ \\
\hline $\begin{array}{l}\text { Control variables: } \\
\text { gender, education, } \\
\text { contribution years to } \\
\text { the pension } \\
\text { fund, work hours, } \\
\text { log of wages, } \\
\text { industry dummies }\end{array}$ & Yes & Yes & Yes & Yes & Yes \\
\hline $\mathrm{N}$ & 3,259 & 3,259 & 3,259 & 3,259 & 3,259 \\
\hline
\end{tabular}

Column 1 shows the OLS results. Columns 2-5 show the marginal effects of a multinomial logit regression (base is expected retirement age of 64). Standard errors are in parentheses. $* p<0.10$, ** $p<0.05$, *** $p<0.01$. Source ROA Public Sector Survey 2011

Table 10 Differences in expected retirement age two years before the announced reform

Columns 1-3 show the OLS results. Standard errors are in parentheses. * $p<0.10$, $* * p<0.05$, *** $p<0.01$. Source Dutch Labour Supply Panel, 2008

\begin{tabular}{lll}
\hline & $(1)$ & $(2)$ \\
& Expected retirement ageExpected retirement age \\
\hline Reference 1950-1954 & \\
Treatment 1955-1959-0.099 & $(0.183)$ & 0.042 \\
\multicolumn{1}{c}{ Treatment 1960-1964-0.242 } & $(0.301)$ \\
& $(0.178)$ & -0.047 \\
Age & No & $(0.513)$ \\
Gender & No & Yes \\
Education & No & Yes \\
Industry sector & No & Yes \\
Constant & $63.585^{* * *}$ & Yes \\
& $(0.130)$ & $62.287 * * *$ \\
Adjusted R-squared & 0.000 & $(2.792)$ \\
$\mathrm{N}$ & 1,636 & 0.043 \\
\hline
\end{tabular}




\section{References}

Baker, M. (2002). The retirement behavior of married couples: Evidence from the spouse's allowance. Journal of Human Resources, 37, 1-34.

Benitez-Silva, H., \& Dwyer, D. (2006). Expectation formation of older married couples and the rational expectations hypothesis. Labour Economics, 13, 191-218.

Bingley, P., \& Lanot, G. (2007). Public pension programmes and the retirement of married couples in Denmark. Journal of Public Economics, 91, 1878-1901.

Bloom, D., Canning, D., Mansfield, R., \& Moore, M. (2007). Demographic change, social security systems, and savings. Journal of Monetary Economics, 54, 92-114.

Borghans, L., \& ter Weel, B. (2012). De economie van zware beroepen: Een verkenning. In N. van Nimwegen, C. van Praag (Eds.), Bevolkingsvraagstukken in Nederland anno 2012. Actief ouder worden in Nederland (pp. 123-137). NIDI-boek nr. 86. Amsterdam: Amsterdam University Press.

Branch, W. (2004). The theory of rationally heterogeneous expectations: Evidence from survey data on inflation expectations. Economic Journal, 114, 592-621.

Bruinshoofd, W., \& Grob, S. (2006). Do changes in pension incentives affect retirement? A stated preference approach to Dutch retirement considerations. DNB Working Paper No. 115.

Burtless, G. (1986). Social security, unanticipated benefit increases, and the timing of retirement. Review of Economic Studies, 53, 781-805.

Carson, R., Flores, N., Martin, K., \& Wright, J. (1996). Contingent valuation and revealed preference methodologies: Comparing the estimates for quasi-public goods. Land Economics, 72, 80-99.

Coile, C. (2004). Retirement incentives and couples retirement decisions. BE Journal in Economic Analysis and Policy, 4, 1-28.

Coile, C., \& Gruber, J. (2007). Future social security entitlements and the retirement decision. Review of Economics and Statistics, 89, 234-246.

CPB. (2011). Pensioenakkoord. Op verzoek van de Tweede Kamercommissie voor Sociale Zaken en Werkgelegenheid, Den Haag.

De Grip, A., Lindeboom, M., \& Montizaan, R. (2012). Shattered dreams: The effects of changing the pension system late in the game. Economic Journal, 122, 1-25.

European Commission. (2011). Demography report 2010. Older, more numerous and Diverse Europeans. Brussels: Commission Staff Working Document.

European Commission. (2012). An agenda for adequate, safe and sustainable pensions. White paper. Brussels: Commission Staff Working Document.

Euwals, R., Van Vuuren, D., \& Wolthoff, R. (2010). Early retirement behaviour in The Netherlands: Evidence from a policy reform. De Economist, 158, 209-236.

Euwals, R., Knoef, M., \& van Vuuren, D. (2011). The trend in female labour force participation: What can be expected for the future? Empirical Economics, 40, 729-753.

Fehr, H., Kallweit, M., \& Kindermann, F. (2011). Pensions reform with variable retirement age. A simulation analysis for Germany. Journal of Pension Economics and Finance, 11(3), 389-417.

Fields, G., \& Mitchell, O. (1984). Economic determinants of the optimal retirement age: An empirical investigation. Journal of Human Resources, 19, 245-262.

Fouarge, D., De Grip, A., \& Montizaan, R. (2011). Pensioenverwachtingen en personeelsbeleid Verslag van de ROA/APG enquête 2011. Maastricht: ROA report ROA-R-2011/9.

Fouarge, D., De Grip, A., \& Montizaan, R. (2012). Hoe gevoelig is de uittredeleeftijd voor veranderingen in het pensioenstelsel?. Tilburg: Netspar Design Paper 07.

Gruber, J., \& Wise, D. (1998). Social security and retirement: An international comparison. American Economic Review, 88, 158-163.

Gruber, J., \& Wise, D. (Eds.). (1999). Social security and retirement around the World. Chicago: University of Chicago Press.

Gruber, J., \& Wise, D. (Eds.). (2007). Social security programs and retirement around the World: Fiscal implications of reform. Chicago: University of Chicago Press.

Gustman, A., \& Steinmeier, T. (1985). The 1983 social security reforms and labor supply adjustments of older individuals in the long run. Journal of Labor Economics, 3, 237-253.

Gustman, A., \& Steinmeier, T. (2004). Minimum hours constraints, job requirements and retirement. NBER working paper 10876.

Gustman, A., \& Steinmeier, T. (2005). The social security early retirement age in a structural model of retirement and wealth. Journal of Public Economics, 89, 441-463. 
Ho, J., \& Raymo, J. (2009). Expectations and realization of joint retirement among dual-worker couples. Research on Aging, 31, 153-179.

Hurd, M., \& Boskin, M. (1984). The effect of social security on retirement in the early 1970s. Quarterly Journal of Economics, 99, 767-90.

Kerkhofs, M., Fouarge, D., \& Ester, P. (2009). Financiële prikkels en geprefereerde pensioenleeftijd. Tijdschrift voor Arbeidsvraagstukken, 25, 20-37.

Kimball, M., \& Shapiro, M. (2008). Labor supply: Are the income and substitution effects both large or both small? NBER working paper 14208.

Krueger, A., \& Pischke, J. (1992). The effect of social security on labor supply: A cohort analysis of the Notch Generation. Journal of Labor Economics, 10, 412-437.

Lamla, M., \& Lein, S. (2008). The role of media for consumers' inflation expectation formation. KOF working papers 201, KOF Swiss Economic Institute.

Liebman, J., Luttmer, E., \& Seif, D. (2009). Labor supply responses to marginal social security benefits: Evidence from discontinuities. Journal of Public Economics, 93, 1208-1223.

Louviere, J., Hensher, D., \& Swait, J. (2000). Stated choice methods. Cambridge: Cambridge University Press.

Manski, C. (2004). Measuring expectations. Econometrica, 72, 1329-1376.

Mastrobuoni, G. (2009). Labor supply effects of the recent social security benefit cuts: empirical estimates using cohort discontinuities. Journal of Public Economics, 93, 1224-1233.

Montizaan R., \& Vendrik, M. (2012). Does Misery Love Company: Exogenous shocks in retirement expectations and social comparison effects on subjective well-Being. Maastricht University, ROA-RM-2012/13.

Montizaan, R., Cörvers, F., De Grip, A., \& Dohmen, T. (2012). Negative reciprocity and retrenched pension rights. Maastricht University, ROA-RM-2012/15.

Organisation for Economic Co-operation and Development. (2011). Retirement-income systems in OECD and G20 countries. Paris: OECD Publishing.

Samwick, A. (1998). New evidence on pensions, social security, and the timing of retirement. Journal of Public Economics, 70, 207-236.

Schils, T. (2005). Early retirement patterns in Europe: A comparative panel study. Amsterdam: Dutch University Press.

Stancanelli, E. (2012). Spouses' retirement and hours of work outcomes: Evidence from twofold regression discontinuity. Bonn: IZA DP No. 6791.

Staubli, S., \& Zweimüller, J. (2011). Does raising the retirement age increase employment of older workers?. Bonn: IZA DP No. 5863.

Stock, J., \& Wise, D. (1990). Pensions, the option value of work, and retirement. Econometrica, 58, 1151-1180.

Van der Wiel, K. (2009). Have you heard the news? How real-life expectations react to publicity. Bonn: IZA DP No. 4064.

Van Erp, F., \& de Hek, P. (2009). Analyzing labour supply of elderly people: A life-cycle approach. The Hague: CPB, Memorandum 179.

Van Erp, F., Euwals, R., de Hek, P., \& ter Rele, H. (2008). Effect van verhogen pensioengerechtigde leeftijd op bruto participatie. The Hague: CPB, Memorandum 198.

Van Soest, A., Kapteyn, A., \& Zissimopoulos, J. (2006). Using stated preferences data to analyze preferences for full and partial retirement. DNB working paper No. 81.

Van Soest, A., \& Vonkova, H. (2013, forthcoming). How sensitive are retirement decisions to financial incentives? A stated preferences analysis. Journal of Applied Econometrics. 